Gut, 1969, 10, 13-18

\title{
Cell turnover in the rat small intestinal mucosa: An appraisal of cell loss
}

\author{
C. A. LOEhrY, D. N. CROFT, A. K. SINGH, AND B. CREAMER \\ From the Gastrointestinal Laboratory, St Thomas' Hospital, London
}

Part I Cell loss in rats with a normal mucosa

The concept of continuous epithelial renewal in the gastrointestinal tract was introduced at the end of the nineteenth century (Patzelt, 1882; Bizzozero, 1888; Schaffer, 1891), and since then labelling experiments with tritium-labelled thymidine have established that epithelial cells are produced in the crypts of the small intestinal mucosa, migrate up onto the villi and are lost at the tips, both in experimental animals (Leblond and Messier, 1958; Quastler and Sherman, 1959; Creamer, Shorter, and Bamforth, 1961) and in man (Shorter, Moertel, Titus, and Reitemeier, 1964; MacDonald, Trier, and Everett, 1964). It has been previously considered that epithelial cells migrate up from the mouth of the crypts directly onto villi on all sides, and it has therefore been assumed that there is an orderly one-to-one relationship of crypts to villi, with one crypt orifice between adjacent villi. In another communication (Loehry and Creamer, 1968) we have established that the crypt-villus relationship in the small intestinal mucosa is more complex than has been assumed, that overall there are many more crypts than villi, that very few of the crypts open out onto villi on all sides, and that, in most cases, much of each crypt opening is adjacent not to villi but to other crypts. The migration therefore of epithelial cells from crypts to villi cannot be a simple direct progression as might be expected from two-dimensional sections. Two possibilities exist: those cells emerging at sites where two crypts are adjacent must either be desquamated here at the crypt mouth or else be channelled round in some way onto villi. Because of this complex crypt-villus relationship it was thought necessary to undertake a reappraisal of cell migration, and, in order to establish whether cells were desquamated at the crypt mouth or channelled onto villi, to study the problem by a consideration of cell loss.

\section{METHODS AND TECHNIQUES}

Desquamated epithelial cells were collected from male albino rats by total small intestinal perfusion. The animals were anaesthetized with intraperitoneal nembutal and the abdomen was opened by a midline incision. A length of $1 \mathrm{~mm}$ diameter PVC tubing was passed through the mouth into the rat's stomach, and guided through the pylorus into the fourth part of the duodenum where it was tied by a silk ligature. Another piece of PVC tubing, $4 \mathrm{~mm}$ in diameter, was passed through a small incision in the caecum and tied in place in the distal ileum. This cannula passed directly into a collecting bottle. It was found that this method of cannulating the small intestine prevented any significant bleeding into the lumen, and when the tubes were in position the small bowel could be perfused without contamination from the stomach, gallbladder, or pancreas. The small intestine with the cannulae was returned to the peritoneal cavity and normal saline infused via a constant flow pump at a temperature of $37^{\circ} \mathrm{C}$. Perfusions were performed at a rate of $250 \mathrm{ml}$ per hour after an initial washout, and hourly specimens were collected.

Two methods were employed in studying the desquamated epithelial cells collected in this way.

1 ESTIMATION OF CELL LOSS BY DEOXYRIBONUCLEIC ACID (DNA) Epithelial cells are desquamated into the lumen of the small intestine with their nuclei, and it is therefore reasonable to assume that the estimation of DNA in the perfusions is a measure of cell loss. Croft, Pollock, and Coghill (1966) have successfully used this technique in evaluating cell loss from the human stomach, and the same principles are here employed in the rat small intestine. The estimation of DNA in the perfusions was performed by the modified diphenylamine method described by Croft and Lubran (1965).

2 EXCRETION OF PARENTERALLY ADMINISTERED ${ }^{50} \mathrm{FE}$ Conrad and Crosby (1963) and Conrad, Weintraub, and Crosby (1964) have shown by autoradiographic studies that ${ }^{59} \mathrm{Fe}$ injected intravenously into iron-replete rats is selectively taken up by the newly formed crypt cells, and then remains in these cells as they migrate up the villi. In the present study the radioactivity of desquamated epithelial cells was counted at time intervals after an injection of ${ }^{59} \mathrm{Fe}$. Thymidine-labelled cells reach the mouth of the crypts at eight to 12 hours and the tips of the villi at one-and-a-half to two days. Although ${ }^{59} \mathrm{Fe}$ 
labels the cells in a different way, being taken up by all cells not yet iron replete, the time sequences would probably be only slightly affected. If widespread desquamation did occur at the crypt mouth there should be an initial rise in radioactivity in the perfusions around the eight-hour period after injection, followed by a second peak at approximately one-and-a-half days when the remaining maximally labelled cells were desquamated from the tips of the villi. If, on the other hand, all cells were channelled onto villi there would only be a single peak at the one-and-a-half-day period.

In the present experiments $10 \mu \mathrm{c}$ of ${ }^{59} \mathrm{Fe}$ was incubated with rat plasma and injected intravenously. The small intestine was perfused at the following intervals after injection: at once, 10 hours, 24 hours, 36 hours, 42 hours, 48 hours, 60 hours, and 72 hours. Three rats were perfused at each of these times and the perfusions maintained for three to five hours on each rat. After each experiment the animal was killed and the small intestine removed, washed and fixed in $10 \%$ formalin. The radioactivity in the hourly specimens and in the intestines was counted in a large well-type scintillation counter.

\section{RESULTS}

DNA EXFOLIATION The desquamated epithelial cells pass down the intestine in small clumps and are washed out into the collecting bottle in this form. Histological sections of the intestine after four hours of perfusion at $250 \mathrm{ml}$ per minute showed no evidence of damage or appreciable trauma to villous structures. The mean DNA excretion rate from five normal rats was $2.2 \mathrm{~m} \mu \mathrm{g}$ atoms of DNA-P per minute (standard deviation 1.06), and is shown in Fig. 5 (part II).

${ }^{59}$ FE EXCRETION The mean and standard deviation of the radioactivity was determined at the various time intervals after the injection of the isotope (Fig. 1). It is apparent that there is a high initial level of radioactivity in perfusions performed immediately after the injection of ${ }^{59} \mathrm{Fe}$, which gradually falls to a baseline at five hours. There is then no further rise in the specimens until 36 hours after injection when a prominent peak appears. After this time radioactivity falls again, until at 48 hours it has once again reached the baseline where it remains for the rest of the time.

Some radioactivity remains in the wall of the small intestine at the end of the various perfusions (Fig. 2). There is a rise up to 24 hours followed by a steady decline.

In order to clarify the significance of these findings some further observations were made.

BLEEDING ${ }^{59} \mathrm{Fe}$ is incorporated into red blood cells, and any bleeding into the gut during the perfusions would give a falsely high level of radioactivity. As a check that the technique did not produce bleeding two rats were perfused after the injection of chromium-labelled red cells. No radioactivity was detected in any of the ensuing specimens. In addition, during the ${ }^{59} \mathrm{Fe}$ experiments all perfusions were tested with the Haemacombostix and were negative for blood.

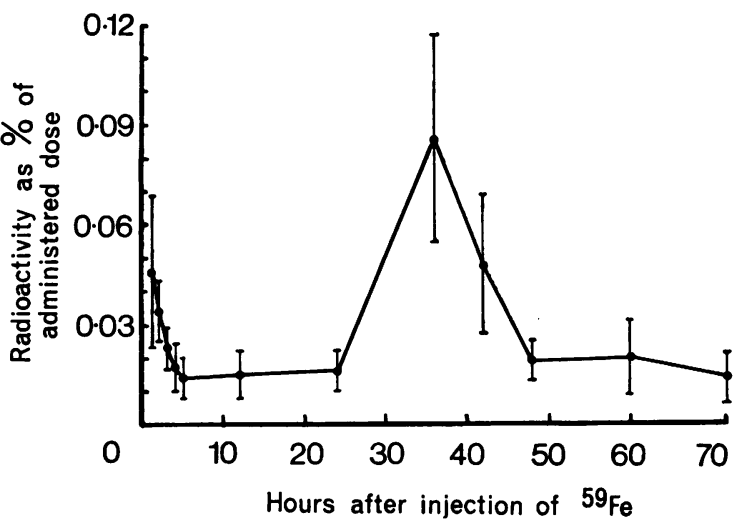

FIG. 1. The mean and standard deviation of the radioactivity in hourly small intestinal perfusions at time intervals after the injection of ${ }^{59} \mathrm{Fe}$.

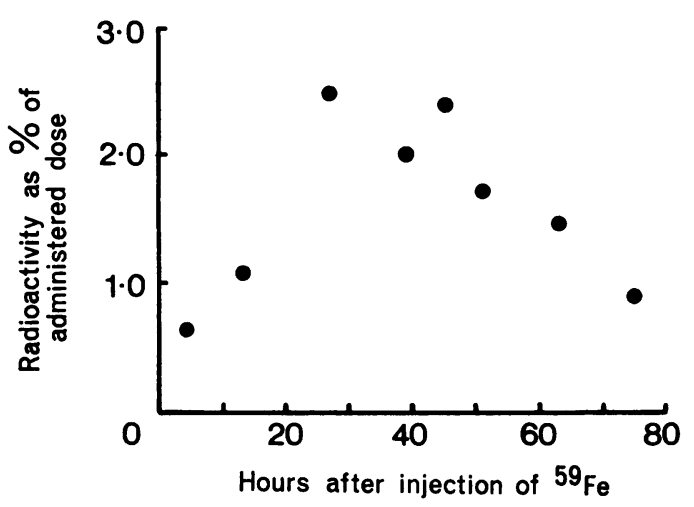

FIG. 2. The radioactivity remaining in the whole of the small intestine at time intervals after the injection of ${ }^{50} \mathrm{Fe}$

CELL EXFOLIATION Before assuming that the rise of radioactivity in the 36 to 42 -hour periods represented the desquamation of labelled epithelial cells, it is important to establish that the radioactivity detected in these specimens did in fact come from exfoliated cells, and was a valid method of measuring cell turnover. It was found that by varying the technique of perfusion by increasing the rate, more cells could be collected in the perfused fluid. A number of 
perfusions were therefore performed at the 36 to $42-$ hour period, and, instead of maintaining a constant flow of saline at $250 \mathrm{ml}$ per hour, the rate of perfusion was altered from hour to hour. This caused a varying hourly collection of cells, and the number of these, as assessed by the DNA rates, could be com-

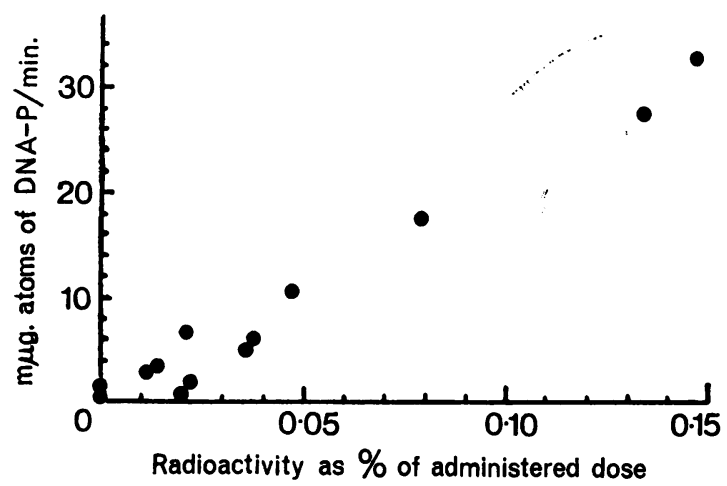

FIG. 3. Comparison of DNA rate with radioactivity in hourly small intestinal perfusions in the period 36 to 42 hours after the injection of ${ }^{50} \mathrm{Fe}$. The rate of perfusion has been varied in hourly specimens.

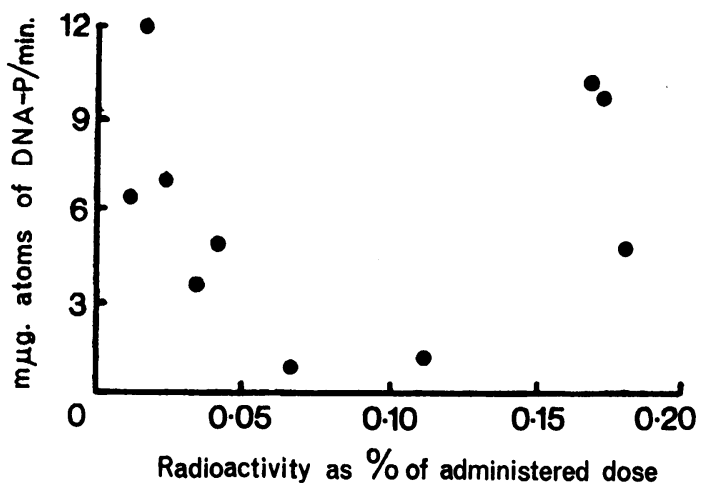

FIG. 4. Comparison of DNA rate with radioactivity in hourly small intestinal perfusion in the period immediately following the injection of ${ }^{59} \mathrm{Fe}$. The rate of perfusion has been varied in hourly specimens.

pared with the levels of radioactivity. A direct relationship was demonstrated at this time, establishing that the radioactivity came from desquamated cells (Fig. 3).

It was considered unlikely that the initial high level of radioactivity in the perfusions directly after injection represented exfoliation of labelled cells, but was probably due to the initially high plasma ${ }^{59} \mathrm{Fe}$ exuding into the gut lumen. A few experiments with varied hourly perfusion rates were therefore performed at this period, and no relationship between cells and radioactivity was demonstrated (Fig. 4).

\section{DISCUSSION}

There are several points raised by these experiments on normal rats. First, provided that the rate of small intestinal perfusion remains constant, the DNA rates in hourly perfusions remain within reasonably constant limits, and below $5 \mathrm{~m} \mu \mathrm{g}$ atoms of DNA-P per minute. While this may not represent an absolutely accurate assessment of cell turnover, it is a valid method of comparing the rate of cell loss in various experimental conditions of the small intestinal mucosa, as in the second part of this paper.

The experiments with ${ }^{59} \mathrm{Fe}$ demonstrate two phases in the excretion of injected iron into the intestinal lumen. The first phase was maximum soon after the injection of the isotope, was unrelated to cell loss, and fell rapidly to a baseline after four to five hours. This period represented the time that ${ }^{59} \mathrm{Fe}$ was present in the plasma in significant amounts (Huff, Hennessy, Austin, Garcia, Roberts, and Lawrence, 1950 ), and the intestinal loss was probably a reflection of the protein-bound iron exuding into the lumen. The second peak at 36 to 42 hours did correlate with cell desquamation and represented the exfoliation at the tips of the villi of those cells that had been maximally labelled after injection. This migration rate of 36 to 42 hours is slightly faster than demonstrated in experiments with tritiated thymidine, and probably represents the differences in the ways that thymidine and iron are taken up into the crypt cells. Thymidine is incorporated in the $\mathbf{S}$ phase of mitosis, and there may follow an interval while the labelled cells undergo further division before commencing migration. Iron, on the other hand, labels all the newly formed cells that are not iron replete, a high proportion of which will have begun to move up the crypts at the time of labelling. In addition, it is clear that with ${ }^{59} \mathrm{Fe}$ some degree of iron uptake must continue in the small intestine for some time after injection, as the radioactivity in the whole intestine rose to a maximum at 24 hours. Presumably this must reflect some continuous movement of iron from the stores to the mucosa. The experiments confirm the suggestions of Conrad and Crosby (1963) and Conrad et al (1964) that the rapid turnover of the small intestinal mucosa provides a method for the excretion of iron, and in addition demonstrate that ${ }^{59} \mathrm{Fe}$ may be used as a method for the study of epithelial cell turnover. In the present experiments the absence of any peak of radioactivity at a time when labelled cells were emerging from the crypts indicates that many epithelial cells must be channelled round onto 
villi at the crypt mouth. The intervillous ridges (Loehry and Creamer, 1968) found between adjacent crypts and joining up onto villi probably represent the migration lines of the epithelial cells in this region.

\section{SUMMARY}

Because it was found that cell migration from crypts to villi in the small intestinal mucosa could not be a direct process, cell turnover was studied in rats by techniques evaluating cell loss. Small intestinal perfusions were performed, desquamated cells collected, and their total volume was assessed by the rate of DNA loss in the perfusions. In addition newly formed crypt cells were labelled with ${ }^{59} \mathrm{Fe}$, and the radioactivity was counted in the cells desquamated at varying time intervals after injection of the isotope. It is likely that the epithelial cells emerging from the crypts move round in some way to be channelled onto villi. The intervillous ridges seen between the adjacent crypts probably represent these epithelial migration lines.

\section{REFERENCES}

Bizzozero, G. (1888). Uber die Regeneration der Elemente der schlauchförmigen Drüsen und des Epithels des Magendarmkanals. Anat. Anz., 3, 781-784.
Conrad, M. E., Jr, and Crosby, W. H. (1963). Intestinal mucosa mechanisms controlling iron absorption. Blood, 22, 406-415.

-, Weintraub, L. R., and Crosby, W. H. (1964). The role of the intestine in iron kinetics. J. clin. Invest., 43, 963-974.

Creamer, B., Shorter, R. G., and Bamforth, J. (1961). The turnover and shedding of epithelial cells. I. The turnover in the gastrointestinal tract. Gut, 2, 110-116.

Croft, D. N., and Lubran, M. (1965). The estimation of deoxyribonucleic acid in the presence of sialic acid: application to analysis of human gastric washings. Biochem. J., 95, 612-620.

-, Pollock, D. J., and Coghill, N. F. (1966). Cell loss from human gastric mucosa measured by the estimation of deoxyribonucleic acid (DNA) in gastric washings. Gut, 7, 333-343.

Huff, R. L., Hennessy, T. G., Austin, R. E., Garcia, J. F., Roberts, B. M., and Lawrence, J. H. (1950). Plasma and red cell iron turnover in normal subjects and inpatients having various hematopoietic disorders. J. clin. Invest., 29, 1041-1052.

Leblond, C. P.. and Messier, B. (1958). Renewal of chief cells and goblet cells in the small intestine as shown by radioautography after injection of thymidine- $\mathrm{H}^{3}$ into mice. Anat. Rec., 132 , 247-259.

Loehry, C. A., and Creamer, B. (1968). The three dimensional structure of the human small intestinal mucosa in health and disease. Gut,

MacDonald, W. C., Trier, J. S., and Everett, N. B. (1964). Cell proliferation and migration in the stomach, duodenum, and rectum of man: radioautographic studies. Gastroenterology, 46, 405-417.

Patzelt, V. (1882). Ueber die Entwicklung der dickdarmschleimhaut. S.-B. Akad. Wiss. Wien., math.-nat. Kl., III abt., 86, 145-172.

Quastler, H., and Sherman, F. G. (1959). Cell population kinetics in the intestinal epithelium of the mouse. Exp. Cell Res., 17, 420438.

Schaffer, J. (1891). Beiträge zur Histologie menschlicher Organe. I. Duodenum. II. Dünndarm. III. Mastdarm. S.-B. Akad. Wiss. Wien., math.-nat. Kl., III abt., 100, 440-481.

Shorter, R. G., Moertel, C. G., Titus, J. L., and Reitemeier, R. J. (1964). Cell kinetics in the jejunum and rectum of man. Amer. J. dig. Dis., 2, 760-763.

\section{Part II Cell loss in rats with an abnormal mucosa}

The aims of this study were to produce a 'flattened' small intestinal mucosa in rats, to study cell loss in this situation, and to compare it with that in normal animals.

Symons and Fairbairn $(1962 ; 1963)$ have investigated the pathological changes in the rat small intestinal mucosa after infestation with the nematode Nippostrongylus brasiliensis. They have demonstrated severe changes by the eighth to tenth days of infection, with shortening or absence of villous projections, lengthening of the crypts, and infiltration with inflammatory cells. They have stressed the resemblance of the histological appearances to those seen in coeliac disease and have demonstrated diminished absorptive capacity (Symons, 1960a and b) and a reduction in the activity of intracellular enzymes during the attack (Symons and Fairbairn, 1963). In a further study Symons (1965) has analysed epithelial cell kinetics with tritiated thymidine, and has demonstrated both an increase in cell production in the crypts and an increase in cell migration on the villi in infected animals. Because of these observations this experimental model was used in the present experiments.

\section{METHODS}

Rats were infested by subcutaneous injections of approximately 5,000 larvae of Nippostrongylus brasiliensis from a stock culture. Small intestinal perfusions were always performed on the ninth day of infection by the technique described in the first part of this paper. The DNA excretion rates were estimated and the radioactivity was counted at once, after 10 hours, 24 hours, 36 hours, 48 hours, 60 hours, and 72 hours after an intravenous injection of $10 \mu \mathrm{c}$ of ${ }^{59} \mathrm{Fe}$. Three rats were perfused at each of these times.

\section{RESULTS}

DNA RATES The DNA rates were compared in five normal and five infested rats (Fig. 5). The mean DNA rate in the control group was $2 \cdot 2 \mathrm{~m} \mu \mathrm{g}$ atoms of DNA-P per minute (standard deviation 1.06), and that in the infected group 6.9 (standard deviation 3.05). The difference between the groups is highly significant $(P<0.001)$, establishing a considerably increased cell loss in the rats with a 'flattened' mucosa.

It is obviously important to exclude other sources 